\title{
Bellas, Casadas, Madres y Solteras IMÁGENES FEMENINAS EN EL CARIBE Colombiano a Comienzos DEL SIGLO XX
}

Por: GLORIA ESTELA BONILLA VÉLEZ

Docente de la Facultad de Ciencias Humanas. Universidad de Cartagena

* Este trabajo hace parte de la investigación "Mujer y Vida Cotidiana en Bolívar 1880-1930", financiado por El Fondo Mixto para la Promoción de la Cultura y las Artes de Cartagena. Agradezco a Liliana Simancas con quien compartí muchas de las preguntas que alumbraron el proyecto. A Estela Simancas, Grey Saldarriaga, Elsy Sierra, Indira Vergara, y Marino Henao en la recolección de información y el trabajo de campo.

Patricia Londoño "El ideal femenino del Siglo XIX en Colombia", En: Historia de las mujeres. Tomo III. Bogotá, Editorial. Norma, pag. 302.

\begin{abstract}
Una mirada desde la alcantarilla puede ser una visión del mundo la rebelión consiste en mirar una rosa hasta pulverizarse los ojos. A. Pizarnik.
\end{abstract}

T a tradicional invisibilidad de la mujer en la historiografía regional y nacional, ha estimulado entre investigadores una creciente preocupación 1 por el fortalecimiento de estudios históricos, que tengan en cuenta a la mujer como actora en los procesos sociales, y una revalorización de la función del matrimonio, la familia, la iglesia y la escuela como factores explicativos del desarrollo de la sociedad.

En el transcurso de los últimos años más mujeres han hecho conciencia de su condición, alentadas por los avances académicos del debate feminista, por la comprensión de la categoría de género como una construcción que reivindica las diferencias entre hombres y mujeres y la igualdad de derechos civiles, y por los cambios cada vez más definitivos en los niveles de participación de las mujeres en aspectos determinantes de la vida social y la producción intelectual. Las discusiones y debates que se desarrollan en el Seminario de Género que tengo a mi cargo en la Universidad de Cartagena así lo demuestran.

Este espacio académico ha hecho posible la proyección de un interés orientado hacia el estudio de los comportamientos y mentalidades de la mujer en el Caribe Colombiano en las últimas décadas del siglo XIX y las primeras del XX. Investigar sobre las mujeres de esa época permite pensar en la identidad femenina, mediante la recuperación de pasajes de la historia de esas mujeres en su cotidianidad. Se trata de develar silencios, discriminaciones, resistencias y logros que en dicho período histórico han padecido, sentido y enfrentado las mujeres en el empeño de ganar espacios propios, definir nuevas imágenes de lo femenino, redefinir y ampliar el papel de hija, esposa, amante, madre, hermana etc. Permite además avanzar en el conocimiento del conjunto de las relaciones de las mujeres y los hombres en los espacios públicos y privados que dejan su testimonio en la prensa de las localidades.

El trabajo se realizó sobre la consulta de periódicos de la época y sus referencias a las mujeres en el rol de esposa, madre o hija. Como lo señala Patricia Londoño, ${ }^{1}$ en Colombia entre 1880 y 1930 aumentó notoriamente la cantidad de textos publica- 
dos alusivos a la naturaleza de la mujer, a su papel en la sociedad, a las virtudes $y$ defectos inherentes a su sexo. Se trata de una miscelánea de escritos en forma de poemas, comedias, pastorales, ensayos, artículos, conferencias, y discursos.

Los escritos aparecidos en periódicos de la época llegaban a un sector minoritario de la población urbana y expresan el punto de vista de la élite. Estas referencias aluden a una mujer en abstracto, desconociendo el abismo cultural y social que había entre los distintos tipos de mujeres que vivían en el país. Investigaciones en este sentido demuestran que las mujeres como grupo homogéneo no existe, sobre ellas inciden las desigualdades sociales, las diferencias de edad, los niveles educativos y culturales. ${ }^{2}$

En un trabajo reciente de la historiadora Liliana Simancas, que señala una de las características del impacto de las publicaciones en las mujeres de finales del siglo XIX y comienzos del siglo XX, observamos que la mayoría de los textos de aquella época eran "material escrito que limita el radio de acción en la población femenina, pues no todas

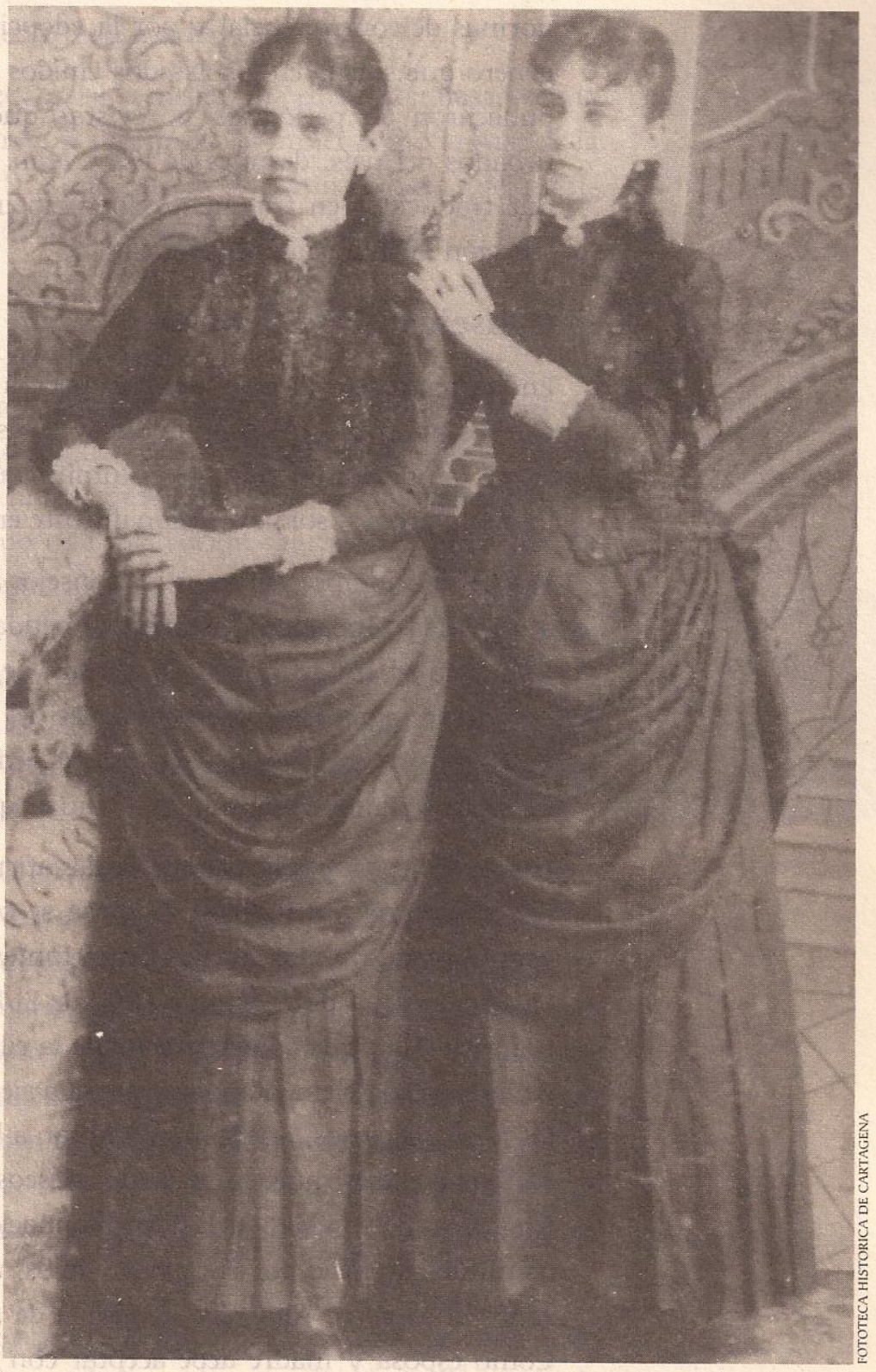
tenían acceso a la información ni la capacidad de leer, también eso implica la visión de un grupo social, el de la élite, ya sea intelectual, política o empresarial, que expresaba la opinión de lo que debía ser el papel de la mujer o los papeles de las mujeres en la sociedad". ${ }^{3}$

Para las mujeres de Cartagena y Barranquilla sobrevivir en medio del control social, las restricciones, las prohibiciones y las exigencias sociales no fue fácil. Pero esto no quiere decir que todas las normas fueran cumplidas. Hubo seguramente algunas mujeres que se atrevieron a subvertir el orden impuesto. "El verticalismo social sufrió resquebrajamiento, pero debieron ocurrir hechos que negaran prácticas arraigadas en el comportamiento de hombres y mujeres".4

La imagen de lo femenino estuvo marcada por la convivencia de nociones de comportamiento creadas por la iglesia, por la respuesta de los sectores populares a las

En este sentido es muy ilustrativo el trabajo de Catalina Reyes. La Vida Cotidiana en Medellín 18901930. Bogotá, Colcultura, 1996.

${ }^{3}$ Liliana Simancas. Una Historia de las Mujeres en el Caribe Colombiano. Trabajo de Grado. Programa de Historia Universidad de Cartagena, Cartagena, Marzo de 1999, pag. 123.

Rafaela Vos Obeso. Mujer, Cultura y Sociedad en Barranquilla 1900-1930. Barranquilla, Ediciones Uniatlántico, 1999. Pag. 153. 


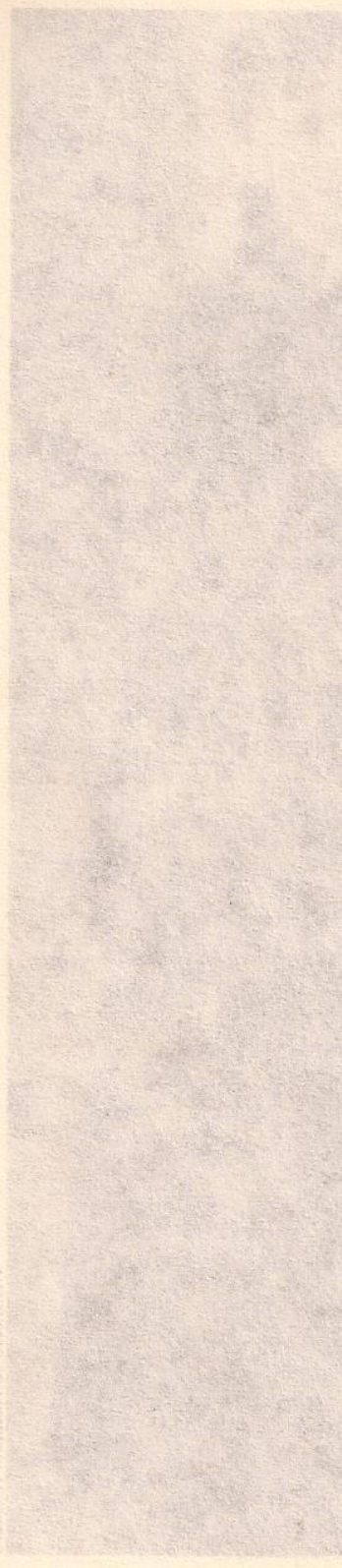

normas de control social y por la adopción de las formas de comportamiento de género que surgía en los Estados Unidos y Europa. No pocos de los textos que se publicaron en periódicos y revistas que circulaban en los principales centros urbanos del país, después de 1920, eran de autores españoles, franceses, ingleses que traducidos en fragmentos parecen indicar cambios importantes en la construcción de imágenes femeninas.

\section{Consejos al Bello Sexo}

En la prensa se evidencia la preocupación por los cambios que se venían operando en el comportamiento y la conducta de las mujeres y a su vez los temores y el recelo por la nueva mujer que se vislumbraba. La mayoría de los autores de los artículos son varones, solo excepcionalmente encontramos mujeres.

A continuación presentamos los consejos a las solteras, a las casadas, a las madres, a las viudas, todas ellas estaban sometidas a unas reglas de comportamiento que las instruían en las formas de actuar, de pensar y de sentir, "las pasiones intimas que despertaban las representaciones del sexo femenino motivan extensas elucubraciones en periódicos y revistas que dedicaron columnas y artículos a las reflexiones masculinas sobre el tipo de mujer que las exigencias sociales demandaban". ${ }^{5}$

Los periódicos y publicaciones locales afirman a las niñas y jóvenes en los patrones del "deber ser". En materia religiosa se construye un discurso que reafirma este asunto como uno de los más importantes en lo que debe enseñarse a las mujeres. La edición del 1 de agosto de 1897 de El Porvenir difunde esta idea de la siguiente manera: "Hay que cuidar mucho de la educación religiosa de la mujer y una sólida instrucción elemental para que siga siendo la reina y el consuelo del hogar. Sólo las ideas religiosas, que tanto encantan a las almas puras, tiernas y sensibles como son las mujeres, pueden llenar los deseos de su corazón, que todo lo apetece, las exigencias de su vida y delicada imaginación. Lo sublime de la mujer virtuosa es su continúo sacrificio por el esposo e hijos, únicos objetos de su ternura. Relegada al retiro doméstico, sólo vive inspirada de sus sentimientos de amor y de religión. Como esposa y madre debe aceptar con resignación todas las penalidades que le acarrean estos títulos, porque son los únicos que protegen su debilidad y ponen a cubierto su honor, siempre a riesgo, siempre amenazado por la seducción y la calumnia".6

Resignación, sacrificio y sufrimiento se erigen en parte inherente de la vida de las mujeres, su mayor virtud, porque formaba parte de su espiritualidad. Siendo solteras o casadas estaban preparadas para soportar "con entereza todo lo que les deparara la vida en el hogar como hijas o como esposas y madres". ${ }^{7}$

Rafaela Vos Obeso. Op. Cit, Pag. 154

- Biblioteca Bartolomé Calvo. (BBC) El Porvenir, Cartagena Agosto 1 de 1897. pag. 2.

Biblioteca Luis Angel Arango. La Opinión, Cartagena, Abril 8 de 1914.

A la pregunta de cuál debe ser la educación más apropiada para la mujer, se especifican una serie de requerimientos tales como: "el verdadero conocimiento de la religión, la corrección más absoluta en el trato con su familia, el conocimiento practico de todos los quehaceres domésticos por aquello de que quien no sabe hacer no sabe mandar, se le debe instruir para que al casarse sea una compañera de su 
marido que le ayude en sus trabajos, sin creerse jamás superior a él, porque la mujer que reconoce su inferioridad frente a su marido es feliz..." ${ }^{18}$

La ideología religiosa cristiana prometía para la mujer una educación basada en la solidez moral, en las buenas costumbres, se reconocía "la mujer como la base de la sociedad. La felicidad del hogar dependerá más que de la fortuna o bienes del marido, del carácter y cualidades morales de la mujer como reina del hogar".

\section{Casadas}

La familia ideal para la mayoría de las personas que escribían en la prensa local era la establecida alrededor del matrimonio católico. Los periódicos locales proyectaban la imagen de aquello que hoy identificamos como el ideal de "amor eterno" base de la alianza matrimonial entendida como una institución sagrada e indisoluble. En 1919, El Estandarte de Barranquilla publicaba un texto con el siguiente contenido: "El matrimonio ha de ser para toda la vida. El amor es la base moral del matrimonio como su ideal, es la perpetuidad, depende de aquí la indisolubilidad del vínculo que une a los sexos, al hombre y a la mujer para constituir la familia, agregamos la santidad porque hay en el hombre algo superior a la materia y a sus instintos naturales". ${ }^{10}$

Sin embargo, en los sectores populares, por encima del estado ideal del matrimonio, lo más común era el concubinato y el madresolterismo. Las investigaciones históricas, por la determinación de los registros de información utilizados, permiten la verificación de una imagen mariana, la mujer casada, representada por el prototipo de mujer de la elite, que se convierte en el "ideal y el sueño de toda mujer" y que las mujeres pobres deseen también alcanzar. Los discursos destinados a la construcción de cierta imagen de mujer recordaban permanentemente a estas, la condición de esposas y de madres de sus hijos, la responsable del buen funcionamiento del hogar. En consecuencia, los códigos sancionarán severamente la infidelidad y el adulterio.

Tal vez el fenómeno más complejo de nuestra cultura hasta tiempo reciente era la manera como el honor familiar estaba anclado en la sexualidad. A diferencia de otras culturas, en las que el honor se fundamenta en la riqueza, en la espiritualidad o el vigor físico, en la nuestra estaba contenido en la pureza sexual de las mujeres. En la vida cotidiana este hecho se tradujo en una especial aprensión de los padres y los maridos hacia sus hijas y esposas, preocupación que cuidaba de reservar la virginidad de aquellas para el matrimonio y que velaba porque todo nacimiento fuera legítimo. El honor del varón, aunque iba más allá de las puertas de su casa, dependía fundamentalmente de la conducta de las mujeres, por ello también el papel de la mujer madre como educadora de hijas. "La responsabilidad del servicio amoroso incluía la comodidad doméstica, el ambiente armonioso y la custodia del honor". ${ }^{11}$

La obligación indiscutible de una esposa era la fidelidad, y esta hacía que la mujer

"Biblioteca Luis Angel Arango. El Iris, Cartagena, Marzo 5 de 1911.

- Biblioteca Central Universidad de Antioquia. El Estuche, Barranquilla, Febrero 9 de 1908, pag. 2.

10 Archivo Histórico del Atlántico. El Estandarte, Barranquilla, Marzo 5 de 1919.

${ }^{11}$ María del Rosario Romero.

Amor y Sexualidad en

Santander Siglo XIX. Bucaramanga, UIS, 1998, pag 94. 


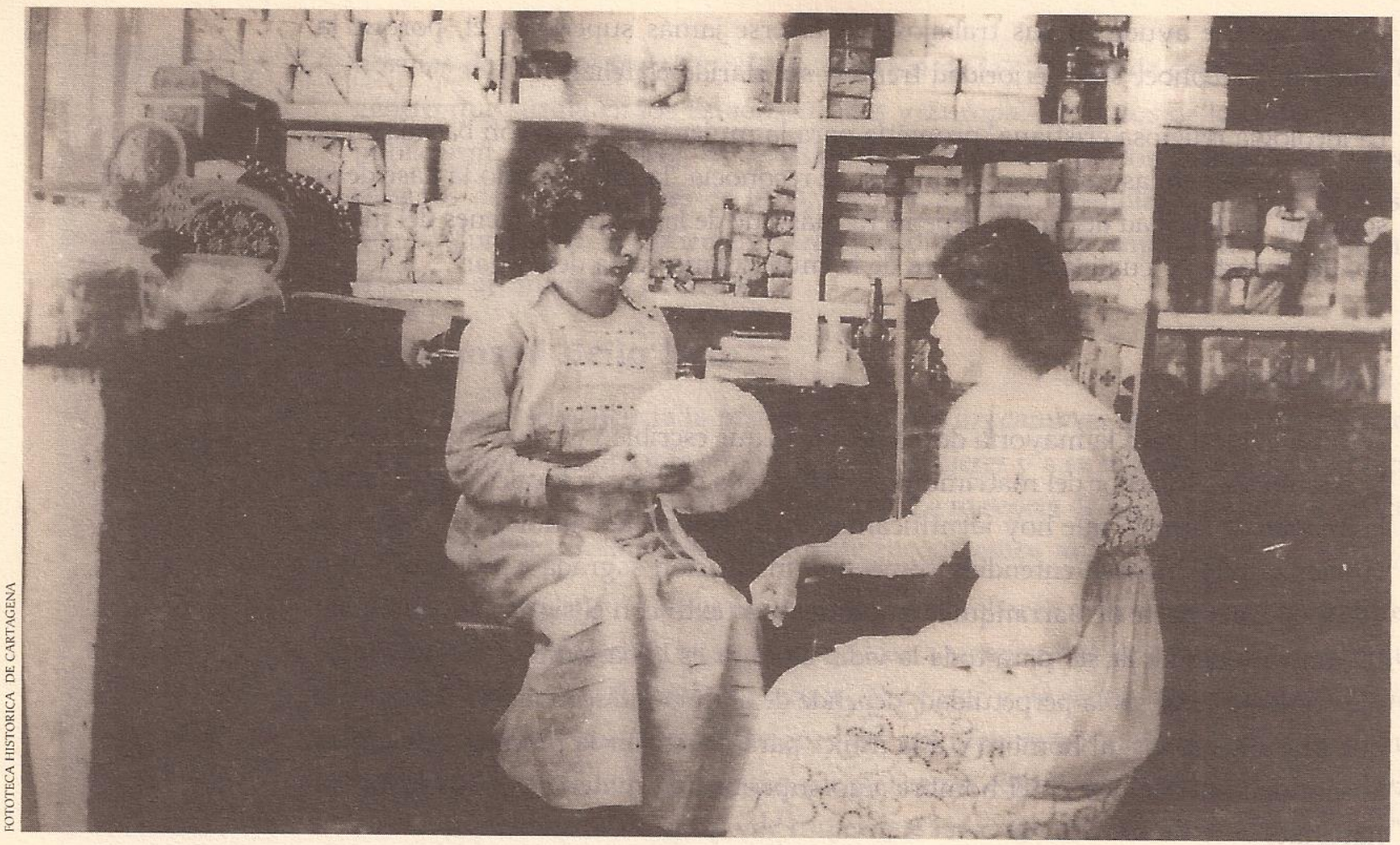

casada viviera en función de los quehaceres domésticos, el cuidado de los hijos y el sometimiento al marido. La monogamia era una de las normas que se imponían a quienes se casaban por lo católico. Se sabe que tal deber era seguido especialmente por la población femenina. La legislación de la época castigaba en forma más severa a las mujeres que incumplían el requisito de fidelidad al marido. ${ }^{12}$ A las mujeres se les hacía sentir el peso de la vigilancia de los preceptos religiosos y de los códigos civiles. Con la infidelidad no solo cometían un grave pecado sino que la legislación y la sociedad las castigaba severamente.

En 1912 en El Porvenir se exaltaba la unión de la familia nuclear en virtud de que para la mujer, "la fidelidad conyugal es la principal virtud, la mujer debe cuidar su reputación y no olvidar que la obligación más sagrada es cuidar al esposo y los

12 Susy Bermúdez El Bello Sexo.. Bogotá, Ediciones Uniandes, 1993, pag. 53.

${ }^{13}$ Archivo Histórico de Cartagena (AHA). El Porvenir, Cartagena, Enero 21 de 1912.

${ }^{14}$ Magdala Velázquez. Condición Jurídica y social de la Mujer. En: Nueva Historia de Colombia, Vol. IV, Bogotá, Planeta, 1989, pag. 9-21.

${ }^{15}$ Eleven P. Stevens. "Marianismo: the other face of machismo in Latín America" en Ann Pesacatello (Editora) Female and Male in Latin América, New York University Press. Susy Bermudez. Hijas, esposas y Amantes, Bogotá Ediciones Uniandes, 1994 , pag. 109 hijos" y que por el contrario, "la infidelidad de la mujer trae las peores consecuencias para la armonía del hogar". ${ }^{13}$ La esposa infiel mancillaba la honra del hogar, y mancharía de por vida al esposo y a sus hijos, lo que podría incluso ocasionar hasta la perdida de los mismos. El código penal, reconocía "estado de ira e intenso dolor". ${ }^{14}$ en los esposos justificando así muchos crímenes contra las mujeres.

El goce sexual no le era permitido a la mujer casada. Se creía en ese momento -y aún hoy- que las mujeres "buenas" y "virtuosas" no debían gozar durante el coito, pues este solo se debía realizar cuando los deberes del matrimonio lo exigían. ${ }^{15}$ Hasta hace muy poco se consideraba que la mujer que tenía una participación activa en la cama y disfrutaba del sexo expresándolo en sus movimientos era una "puta" y el marido empezaba a desconfiar de ella porque "quien sabe con quien se había acostado y había aprendido tanto". 
A la mujer no le bastaba con ser fiel, debía además ser discreta para no provocar celos del esposo, "a él sólo se debe, no puede andar mostrándose por ahí, dando de que hablar, en el hombre los celos lo hacen ciego e implacable por eso no debe generar desconfianza en su marido". ${ }^{16}$ El honor viril depende de la lealtad y honradez de la mujer. El más leve descuido por parte de la mujer pone en entredicho el honor del esposo, del hermano y del padre, quienes se veían enfrentados al compromiso de vengar afrentas y vigilar que las mujeres de la familia no perdieran la virginidad, que deben llevar al matrimonio como prenda de virtud, de recato y de pudor. El honor era asunto de hombres, aunque encarnado en sus mujeres. Toda afrenta al honor familiar era vivida con especial dramatismo, por tanto, las familias y la comunidad cuidaban celosamente de conservar el orden social, sexual y moral.

Si los celos estaban plenamente justificados en el hombre, en la mujer en cambio no eran bien vistos. La esposa amará respetando la libertad del marido y nunca deberá desconfiar o ser celosa. "La mujer celosa es insufrible y se hace odiosa con sus impertinencias. Fastidiando a su marido, lo aburre y sólo consigue que la deje". ${ }^{17}$ La esposa ideal tiene plena confianza en su esposo, sacrifica su gusto, su interés, su comodidad y su bienestar al querer del otro. Si el marido ha sido infiel, ella debe perdonarlo. "El hombre necesita holgura y libertad en un sentido más fundamental que su consorte. La mujer en cambio necesita concentración y emoción más que el hombre". ${ }^{18}$

A las mujeres se les preparaba para ser buenas amas de casa y para lograrlo debían cumplir algunos requisitos, exigencias que van cambiando con el tiempo. Por ejemplo para fines del siglo XIX una "buena ama de casa era la esposa complaciente, dócil, sumisa, obediente, paciente y dulce, que le evita malos ratos al esposo y la encargada de conservar la paz y la tranquilidad del hogar". ${ }^{19}$

La mujer casada además de atender a los hijos, debía procurar la tranquilidad del esposo al llegar a casa "evitar que visitas inoportunas le interrumpieran el reposo de la vida doméstica y que los hijos no tengan acceso cerca de él más que en momentos oportunos, limpios y compuestos para distraerlo con sus gracias". ${ }^{20}$

Otras de las virtudes de la mujer que se exaltan en la prensa, a comienzos de la década de 1920, es el silencio y la prudencia. Las mujeres que hablan mucho están expuestas a la burla y la crítica, a hacer el ridículo y obtener la sanción social. "La mujer perfecta es la que es modesta, casta, diligente, hacendosa, silenciosa, que se levanta a las cinco de la mañana, prende el fogón, reparte a sus criadas el oficio del día, alaba a Dios. La mujer casada esta cerrada a los chismes y a la farándula de los vecinos, nunca de sus labios saldrían murmuraciones, su hogar será un recinto sacrosanto, todo en su casa estará limpio, elegante y ordenado". ${ }^{21}$

En las reuniones sociales la mujer debía permanecer en silencio, mostrar especial afecto a su marido, con sus acciones, palabras y gestos. De tal manera que la gente se dé cuenta del cariño y estimación a él. Una actitud contraria seria muy mal vista. "Hay muchas a quienes agrada empequeñecer a sus maridos delante de la
${ }^{10}$ AHA. El Progreso, Barranquilla, Mayo lo de 1911. La mujer es un objeto para ser visto por el sujeto masculino. Si es casada, es objeto privado para la mirada de su dueño. Ortega y Gasset en Dussell, Enrique. Liberación de la Mujer y Erótica Latinoamericana., Bogotá, Nueva América, 1980. Citado por María del Rosario Romero. Op Cit. Pag. 104.

17 Biblioteca Universidad de Antioquia. Diario Comercial, Barranquilla, Febrero 15 de 1908.

18 Biblioteca Luis Angel Arango., El Porvenir, Barranquilla, Julio 27 de 1929 pag. 14.

10 Biblioteca Luis Angel Arango. El Estuche, Cartagena, Abril 12 de 1898.

${ }^{20}$ AHA. Diario del Comercio, Barranquilla, Abril 14 de 1924.

2 AHC. El Porvenir, Cartagena, Mayo 14 de 1921. 
2 AHA. La Prensa, Barranquilla, Diciembre 24 de
1930 .

${ }_{23}$ María del Rosario Romero. Op. Cit, pag. 98-99.

${ }^{24}$ Carta de Simón Gutiérrez de Piñeres a sus hijas. Mompox Julio 10 de 1914

Un archivo privado de Celedonio Piñeres. Cartagena, facilitado por Teresa Ripioll.

${ }_{25}$ AHA. Diario del Comercio, Barranquilla, Noviembre 23 de 1922 pag. 6. gente: les ordenan autoritariamente miles de cosas y les hacen lucir su sumisión en presencia de sus amigas. Es común que en conversaciones con amigos se apoderen de la conversación con observaciones frívolas o poco interesantes privando al hombre de lo que para él podría ser una discusión interesante. Las mujeres calladas rara vez son fastidiosas. Las habladoras son las que desesperan a los hombres. Las mujeres fastidiosas acaban con el amor".22

Además del silencio, la humildad, la paciencia, la resignación, la abnegación, la prudencia y la discreción, como lo afirma Rosario Romero para el caso de Santander, eran virtudes de esposa que debían "practicarse en todos los instantes de la vida con espontaneidad y cariño", que tenía como finalidad hacer "el varón centro, razón, eje y príncipe único, a costa de la anulación personal de la mujer. En esto consistía el amor dentro del matrimonio, entrar en una muerte del ser femenino". ${ }^{23}$ Era la negación de la mujer, una práctica estructural de larga duración, que tendrá como consecuencia su invisibilización en toda la historiografía del siglo XX

Este ambiente llevaba al hecho que frente a los maltratos del esposo la mujer callara, solo excepcionalmente en la prensa y en los asuntos de policía se ventilan estas denuncias. El ideal exigía que la imagen fuera mantenida por encima de la realidad. Por deber y por necesidad debía la mujer disculpar, acatar y defender a su marido. "Bienaventurados los mansos de corazón", reza el evangelio, la mujer debía aprender a dominarse y a reprimir sus sentimientos y sus impulsos. Amar es enmudecer, pues el control de sí se logra cerrando con esfuerzo la boca.

A la mujer no solo se le reprimía la posibilidad de hablar, también la risa era censurada en ellas. La preocupación de un padre por salvar a sus hijas de la senda prohibida por los preceptos morales, religiosos y los códigos civiles, se expresa con gran puntualidad en la carta que Simón Gutiérrez de Piñeres envió a sus hijas desde Mompox en 1914 para recomendar las normas de buen comportamiento de la siguiente manera: "Las mujeres que hablan mucho, que de todo se ríen no llegan siquiera a ser esposas, la risa a carcajadas es un defecto femenino que debe corregirse, las mujeres deben tener jovialidad, alegría, franqueza, seriedad que es su mejor trinchera si quiere permanecer digna. El pudor, y el recato es el mejor brillo de la mujer moderna, el aprecio de una mujer está en su tono y en su seriedad para accionar, callar y decir lo poco que convenga. No deben olvidar que la duda y la desconfianza son las mejores seguridades". ${ }^{24}$

En el mismo sentido de la carta de este padre momposino, en 1922 el Diario del Comercio de Barranquilla en un articulo publicado el 23 de noviembre reafirma las normas de conducta de las mujeres: "Ama y respeta a tus suegros, escucha sus consejos y cuídalos como si fueran sus padres; tus secretos no los confíes más que a tu marido, no alces la voz en ningún lugar, la modestia y la moderación distingue a la mujer culta; no sospeches nunca de la infidelidad de tu marido, haz grato el hogar a fin de que tu esposo no vaya a buscar distracción en otras partes no le des tiempo ni comodidad para fastidiarse ni entregarse a otras pasiones no seas exigente, porque la exigencia fatiga, importuna y disgusta al marido". ${ }^{25}$ 
Así como a las mujeres se les aconseja para el matrimonio, especialmente a las mujeres de la élite, para no perder la oportunidad de escoger un buen marido, a los varones también se les va a insistir en "el arte de elegir esposa", que como lo planteaba un articulista de El Porvenir en 1924: "elegir esposa es el problema más difícil de todos los hombres. Lo primero que se debe tener presente es que una mujer puede cambiar de opiniones, pero no de costumbres ni de procedimientos. Si una mujer por ejemplo, ha adoptado el sistema de las lágrimas, no lo modificará, aunque el marido haga todos los esfuerzos, no lo conseguirá. La mujer cree que con sus ojos húmedos y brillantes y su expresión de víctima buscará quien la consuele. Un hombre por seguir los caprichos de la mujer puede cambiar su manera de vestir, en cambio ellas no cambian nunca cuando creen que algo les queda bien. Ellas siguen la moda. Lo único que ella intentará cambiar, para satisfacer a su esposo, es el modo de pensar". ${ }^{26}$

En la prensa regional era frecuente encontrar artículos dedicados a guiar el comportamiento social de los sexos y su actuar en los espacios públicos y privados, consejos a las solteras, las niñas, las casadas, las viudas, y a los varones. Lo mismo que reglas de urbanidad y buena educación "Al fumar no echar humo a las personas, no comer en la calle, no obstruir las puertas de la iglesia, teatro, reuniones públicas y hoteles, no hacer visitas ni demasiado largas ni demasiado cortas, no dejen de dar las gracias a quien les cede la silla en un carruaje o al que les paga el billete o el valor del pasaje. No llevar horizontalmente el bastón, ni el paraguas". ${ }^{27}$

A las casadas se les aconsejaba "procurar que la luna de miel no se azucare demasiado para que se prolongue por mas tiempo. Vestirse para el marido como se vestía para con los novios. No permitir criadas guapas. No confíes en la virtud de las que te parezcan feas; hacer del hogar un refugio, no la cárcel de tu esposo". ${ }^{28}$

Otra imagen frecuente hace relación al trabajo y al papel de proveedor del hogar en la figura del hombre. En las primeras décadas, todavía se sigue pensando que los que deben trabajar son los hombres y les parece una inconveniencia que las mujeres lo hagan, parecería que los oficios del hogar no fueran una forma de trabajo. Claro, en este momento la alusión se hace al trabajo remunerado. En este sentido la prensa también es reiterativa: "la tesis de que la mujer también debe trabajar es absurda y tonta y será abolida definitivamente, sólo deberán trabajar los hombres, las mujeres son para embellecer el hogar y la sociedad, quien debe mantener el hogar es el marido". ${ }^{29}$

Este forma de pensar se conecta directamente con la creencia de que el matrimonio da "seguridad" y que casándose la mujer no tiene de que preocuparse. Para la mujer la autonomía no era un principio fundamental, porque, como se afirmaba en la edición de El Porvenir de Barranquilla del 27 de julio de 1929, que ya hemos referido: "la holgura y la libertad eran características masculinas, en cambio la concentración y la emoción eran atributos femeninos indispensables para la supervivencia de la institución familiar". ${ }^{30}$ Mientras que en El Diario del Comercio de esa misma ciudad en su edición del 12 de diciembre de 1922 planteaba esta cuestión en
${ }^{26}$ AHC. El Porvenir, Cartagena, febrero 23 de 1924, pag. 2.

27 Biblioteca Universidad de Antioquia, Márgenes, Cartagena, Abril 8 de 1908.

2s AHA. El Nuevo Diario, Barranquilla, Febrero 21 de 1914

29 AHC El Mercurio, Cartagena, Marzo 31 de 1928.

${ }^{30} \mathrm{AHC}$. El Porvenir, Barranquilla, Julio 27 de 1929 pag 14. 
Archivo Histórico del Atlántico. (AHA) Diario del Comercio, Barranquilla, Diciembre 12 de 1922.

32. El Bodegón, Cartagena Noviembre 11 de 1925.

33 AHA. El Liberal, Barranquilla Febrero 8 de 923. Citado por Rafaela.Vos Op. Cit, pag. 157.

${ }^{14}$ AHA. Diario del Comercio, Barranquilla, Abril 21 de 1914.

${ }^{15}$ AHC. El Porvenir, Cartagena, Marzo 2 de 1879.

${ }^{36}$ AHC. El Porvenir, Marzo 22 de 1914. términos de la felicidad doméstica así: "la mujer que más felicidad procura es la dueña de casa que sabe tenerlo todo en orden y con economía". ${ }^{31}$

Aunque, pensamientos como la anterior constituían la nota predominante, es necesario resaltar algunos cambios en el discurso sobre el ideal femenino en el que para la segunda década del siglo XX se introducen nuevas percepciones del quehacer de la mujer. Según El Bodegón de Cartagena, publicación de abierta crítica del orden social y cultural urbano de los años veinte, en su edición del 11 de noviembre de 1925 se decía que "la buena ama de casa ha de educar sus sentimientos estéticos y refinados, no debe vestir con modas exageradas, ni con el cabello engomado. Aunque vista con ropas de trabajo debe esforzarse por ofrecer un aspecto agradable, debe gustarle la pintura, la música, la literatura, las labores artísticas, ha de tener un carácter agradable, debe saber de pedagogía para tratar a los niños". ${ }^{32}$

\section{Madres}

Además del rol de esposa, la mujer tenía otro de madre. Prepararlas y educarlas para cumplir su deber de madre era el principal requisito, según el texto que rescata Rafaela Vos de El Liberal de Barranquilla, "para lo cual debía disponer su voluntad, corazón, imaginación y su cuerpo. Mujeres incapaces de faltar, fieles, puras, religiosas, bondadosas, dulces, complacientes y amables". ${ }^{33}$

La mujer ya no sólo debía cumplir la misión de buena madre y esposa, también estaba obligada a ser maestra "debía educar a los hijos hacerlos hombres dignos, valientes, abnegados, con sanos principios de amor al trabajo y al estudio." Una misión muy importante de la madre era justamente "enseñar a los niños nociones de moral y formar desde temprano sus corazones". ${ }^{34}$

La preocupación porque las madres fueran educadoras de los hijos y a la vez se les educara para ello se percibe tenuemente desde fines del siglo XIX "las madres deben ser las primeras maestras de sus hijos, hay muchos que creen que la mujer es inferior intelectualmente al hombre y por eso quieren reducirla a la costura, a la cocina y a la alcoba. Mientras más instruida es la mujer, más activa es para el desempeño de los deberes domésticos y está mas enfrentada para los contratiempos de la vida". ${ }^{35}$

El ser "buena madre" y el estado de la maternidad van a ser temas reiterados en la prensa. El ejercicio de la maternidad y todo el conjunto de representaciones sociales sobre este estado gozaba de un alto reconocimiento. A la madre como imagen y con frecuencia en la práctica, se le rinde culto, a ella se le encargan las principales funciones de socialización y crianza de los hijos, la responsabilidad de forjar mujeres y hombres íntegros, productivos y funcionales a la sociedad. "La cualidad mas apreciada en la mujer es el pudor del amor y el instinto materno. Ningún papel es tan grande e importante como el que la mujer ha desempeñado cerca del hombre siendo su compañera, guía de la familia, educadora de los hijos. Su labor 
se extiende a las más altas esferas del pensamiento y los íntimos afectos del alma". ${ }^{36}$ La responsabilidad de la maternidad en cuanto a la educación de los hijos y de "velar por el bien y la virtud", es mas rigurosa en cuanto a la educación de las niñas; "a quien la madre vigilara para que no falte a sus deberes de urbanidad y cortesía, le enseñaremos las reglas de galanteo, la queremos reservada y desenvuelta, sencilla, agradable, graciosa, compasiva y piadosa... Desarrollar en ellas el instinto de maternidad. Y velar porque la hija tenga conocimientos de la puericultura". ${ }^{37}$

La sacralización de la maternidad en las imágenes sociales, no corresponde a las demandas que la sociedad le hace a la mujer, generándose una contradicción entre el ideal y lo que se hace. Se piensa que la madre es la reina del hogar y se le construye un pedestal, pero las mujeres de los sectores populares en su lucha diaria por sobrevivir distan mucho de esa imagen idílica de las mujeres de la elite.

La publicidad también exaltaba la maternidad y la preñez, recomendaba toda suerte de productos que debían consumir las mujeres embarazadas y parturientas. "El compuesto Mitchelle reduce los horribles sufrimientos del parto, tomarlo diariamente evita molestias a la madre y trae beneficios al bebé que nace sano, hermoso y robusto". ${ }^{38}$

\section{Solteras}

Las restricciones que imponían a las solteras inculcaban formas de comportamiento cuyos principios morales se asociaban con la virginidad, en la cual radicaba la inocencia, la castidad y "valoración social". ${ }^{39}$ La sociedad y la familia desde niñas las forman para que cumplan la misión de forjadoras de la moral y la virtud dentro del hogar. La niñez y la adolescencia femeninas se dedicaban por completo a la preparación para el matrimonio. El matrimonio era deseable y el estado ideal de la mujer, por ello se le dan consejos para "elegir el buen marido", "para atrapar esposo", "como escoger el consorte", etc.

A las solteras se les va a insistir en la necesidad de saber escoger marido, especialmente para las mujeres de la élite. Era costumbre que las familias pudientes, enviaran a sus hijas solteras a Europa y Estados Unidos para que se relacionaran con jóvenes de su misma condición civil y tuvieran roce social. Para encontrar marido se podían seguir algunos consejos: "tener mas sentido común y menos coquetería, más ocupaciones útiles y menos música, escudriñar mejor los misterios de la casa y menos los cuentos de salón, repasar las camisas y las medias y no hacer majaderías. Leer la "cocina casera" y abandonar los periódicos de moda. No sacar a relucir trajes que espantan los bolsillos de los candidatos a matrimonio, menos balcón o ventana y más costura, menos charla y más juicio. Probar a los hombres que encontraran una buena esposa y no "un mueble de lujo", o de estorbo y peligroso para su tranquilidad y para su honor. Ser en fin modesta, virtuosa, fiel, amable y discreta". ${ }^{40}$

La imagen construida de lo que debería ser una "señorita" es contundente y avasa-
37 AHC. El Porvenir, Cartagena, Mayo 7 de 1924.

${ }^{3 s}$ AHA.Diario de la Costa, Cartagena, Enero 14 de 1918.

39 Rafaela Vos Obeso. Op. Cit. Pag. 156.

4 AHC. El Porvenir, Cartagena, Abril 7 de 1905 , pag. 3. 
${ }^{11}$ BBC. El Bodegón. Cartagena, marzo 30 de 1929 , pag. 70 .

${ }^{12}$ AHA. El Derecho, Barranquilla, Abril 12 de 1916. Pag. 5.

43 AHA. EL Nuevo Diario, Barranquilla, Abril 15 de 1914.

" AHA Diario del Comercio, Barranquilla, Noviembre 14 de 1922, pag. 6. lladora. "Se necesita una señorita que respete a Dios, que sepa obedecer a sus padres, ser modesta y honesta, que no mastique chicle ni abuse del colorete, que se vista con gusto personal, que siempre esté contenta, que salga a la calle nada más que a lo necesario, que no hable solo de modas y del prójimo, que sepa de labores domésticas, que domine un idioma, y toque al menos un instrumento musical, que no se encuentre en las fiestas, que no se embriague ni fume, que no derroche en prendas de vestir ni en joyas, que sea discreta aún con sus amigas, que sepa las labores domésticas". ${ }^{41}$

A las jóvenes la prensa les mostraba un cuadro de lo que no "deberían ser" y evitar convertirse en "muchachas odiosas y detestables y por su coquetería se quedaran solteronas porque no habrá hombre que quiera cargar con ellas; las que pasan el día cargando perros y gatos. Las que se llaman "señoritas de la cream" no siendo más que chismosas vulgares las que no saben hacer oficios de la casa. Las que viven de visita de seis a seis". ${ }^{42}$

La edad en las que la mujer debería casarse oscilaba entre los 18 y los 25 años, después de esta edad ya era considerada solterona " y produce una compasión infinita la mujer que cumpliendo los treinta años no se ha casado, ya ha perdido la esperanza de ser madre (se convierte en objeto de lástima), en un ser digno de piedad, y las pobres enferman de despecho y pesadumbre, esto las hará egoístas y malvadas, monstruos de rencor y de venganza". ${ }^{43}$

Esta normatividad y reglas de conducta permiten acceder a las representaciones sociales y culturales sobre los comportamientos femeninos, la manera de pensar, sentir y actuar de hombres y mujeres. El mundo masculino había construido un ideal de mujer que la representaba afectiva y amorosa con una serie de atributos como la docilidad y la obediencia que garantizaban la tranquilidad del marido y del hogar, la armonía de las relaciones familiares y el éxito del matrimonio.

En la preocupación de conseguir un marido bueno, las mujeres jóvenes deberían observar una reglas como "ser sencillas y modestas, amar su casa, honrar sus padres, no exhibirse en fiestas, bailes reuniones o paseos, ser discreta en su juicio y reposada en sus ideas, no dejarse arrastrar por amoríos pasajeros y sólo atender a hombres formales que tengan la intención de llevarla al altar huyendo de los galantes y jovenzuelos, ser honrada y no dar motivo para que los hombres tengan que ocuparse de ellas". ${ }^{44}$

La soltería en la mujer era considerada una desgracia, inspiraba lástima, la expectativa social de casar a la mujer era muy fuerte, algo así como la meta para la cual debía prepararse desde su más temprana edad. Y aunque el ideal era contraer matrimonio con un buen hombre, en última instancia había que casarse con alguno sin importar que no reuniera todos los requisitos de ideal tipo.

El masculino y el femenino eran dos lenguajes desencontrados y desencantados en lo que se refiere a la convivencia matrimonial, y en su imaginario. Son muchos los chistes y las bromas que evidencian como el significado de la vida matrimonial era 
distinto para cada uno. El matrimonio para la mujer era su mayor deseo, "se hacían las novenas a San Antonio para conseguir novio"; para el hombre en cambio la conyugalidad era como un infierno, un foco de desdicha, un riesgo. Así lo expresa un satírico diálogo espiritista publicado en El Bodegón el 30 de agosto de 1925: "¿Es el espíritu de mi esposo el que está presente?- Si contesta una voz cavernosa. ¿Pepe amado mío eres feliz? Si muchísimo imás que cuando vivías conmigo? Oh muchísimo más". ${ }^{45}$ El hombre pronto se cansa del matrimonio y lo que era "una luna de mieles se convierte en una luna de hieles, al año el matrimoniado esta cansado de oír llorar al niño, de ver su mujer desgreñada y convertida en una pantera". ${ }^{46}$

La mujer soltera, casada, viuda o en unión libre que estuvo sometida al varón en condición de padre, hermano, esposo o amante le fue reforzado todo ese sistema de representaciones, a partir de los consejos verbales o en cartas de sus padres y a través de los periódicos de la época. Y finalmente la preparaban para un buen desempeño de esposa, madre y organizadora del hogar.

El lugar de avance de nuestra investigación coincide con la perspectiva que se abre en los resultados de investigaciones como la de Rosario Romero ${ }^{47}$ que plantea la posibilidad de estudiar otros puntos de vista sobre las imágenes femeninas y sus roles dentro de una perspectiva social. En este sentido también planteamos la necesidad de superar el estudio histórico de la mujer en esa etapa que podríamos llamar pedagógica, es decir aquella en la que esta siendo formada y formando para; y abordar otras categorías como la de esposa-madre convertida en suegra u otras muy poco mencionadas en los documentos que hemos utilizado en la investigación como la mujer hermana, la mujer abuela y la mujer tía.

\section{BIBLIOGRAFIA.}

Archivo Histórico De Cartagena (A. H. C.).

Archivo Histórico Del Atlántico (A. H. A.).

Biblioteca Bartolomé Calvo, Cartagena.

Biblioteca Luis Ángel Arango, Bogotá.

Biblioteca Universidad de Antioquia, Medellín.

ANDERSON, Bonnie y otras. Historia de las Mujeres: Una Historia Propia, Barcelona: Crítica, 1991.

BERMúdEz, Susy. El Bello Sexo, Bogotá: Uniandes, 1993.

$$
\text { , Hijas, Esposas y Amantes, Bogotá: Uniandes, } 1994 .
$$

DUSSELL, Enrique. Liberación de la Mujer y Erótica Latinoamericana, Bogota: Nueva América. REYES, Catalina. Vida Cotidiana en Medellín 1890-1930. Bogotá: Colcultura, 1996.

ROMERO, María del Rosario. Amor y Sexualidad en Santander Siglo XIX, Bucaramanga: UIS, 1998. SIMANCAS, Liliana. Una Historia de las Mujeres en el Caribe Colombiano.

Trabajo de Grado. Programa de Historia. Universidad de Cartagena, 1999.

VELÁSQUEZ, Máguala. "Condición Jurídica y Social de la Mujer". En: Nueva

Historia de Colombia, Vol. IV, Bogotá: Planeta, 1989.

VOS Obeso, Rafaela. Mujer, Cultura y Sociedad. En: Barranquilla 1900-1930.

Barranquilla: Uniatlántico, 1999.
${ }^{45}$ AHC. El Porvenir, Abril 4 de 1897.

th BBC. El Bodegón, Cartagena, Agosto 30 de 1925

${ }^{47}$ María del Rosario Romero. Op. Cit, Pag. 106. 